\title{
Striated Border
}

National Cancer Institute

\section{Source}

National Cancer Institute. Striated Border. NCI Thesaurus. Code C33634.

A dense covering of uniform microvilli located on the apical surface of certain epithelial cells, including the lining of the small intestine, which serve to increase the surface area of the cell, thereby facilitating absorption. 